\title{
Providing Schools with Enough Resources to Deliver Quality Education in the Philippines
}

\section{Introduction}

Providing schools with direct funding to meet their operational needs is the cornerstone of the government's efforts to strengthen school-based management in the Philippines. Over the past five years, funds that the government has provided directly to schools to support their maintenance and other operating expenses (MOOE) have increased by 45 percent in real terms, demonstrating the government's commitment both to increasing operational funding and to providing schools with the funding that they need to implement their own improvement plans.

Evidence from the Philippines and elsewhere shows that increased school funding and effective school-based management (SBM) can lead to more efficient use of resources and, ultimately, to better education outcomes. Evaluations of a school-based management program in the Philippines have shown that this program coupled with the provision of school grants led to significant improvements in school performance. ${ }^{2}$ Over a three-year period, the introduction of SBM and the provision of grants improved the scores of Philippines students on the National Achievement Tests (NAT) by 4 to 5 percentage points (approximately 0.25 standard deviations). ${ }^{3}$ These findings echo similar results from other countries that, on the whole, show that schoolbased management reform, if implemented effectively, can improve education outcomes over time. ${ }^{4}$

The aim of this policy note is to assess the current systems that govern the allocation, transfer, and use of MOOE funds for schools. It uses data collected as part of the PETS-QSDS study from a nationally representative

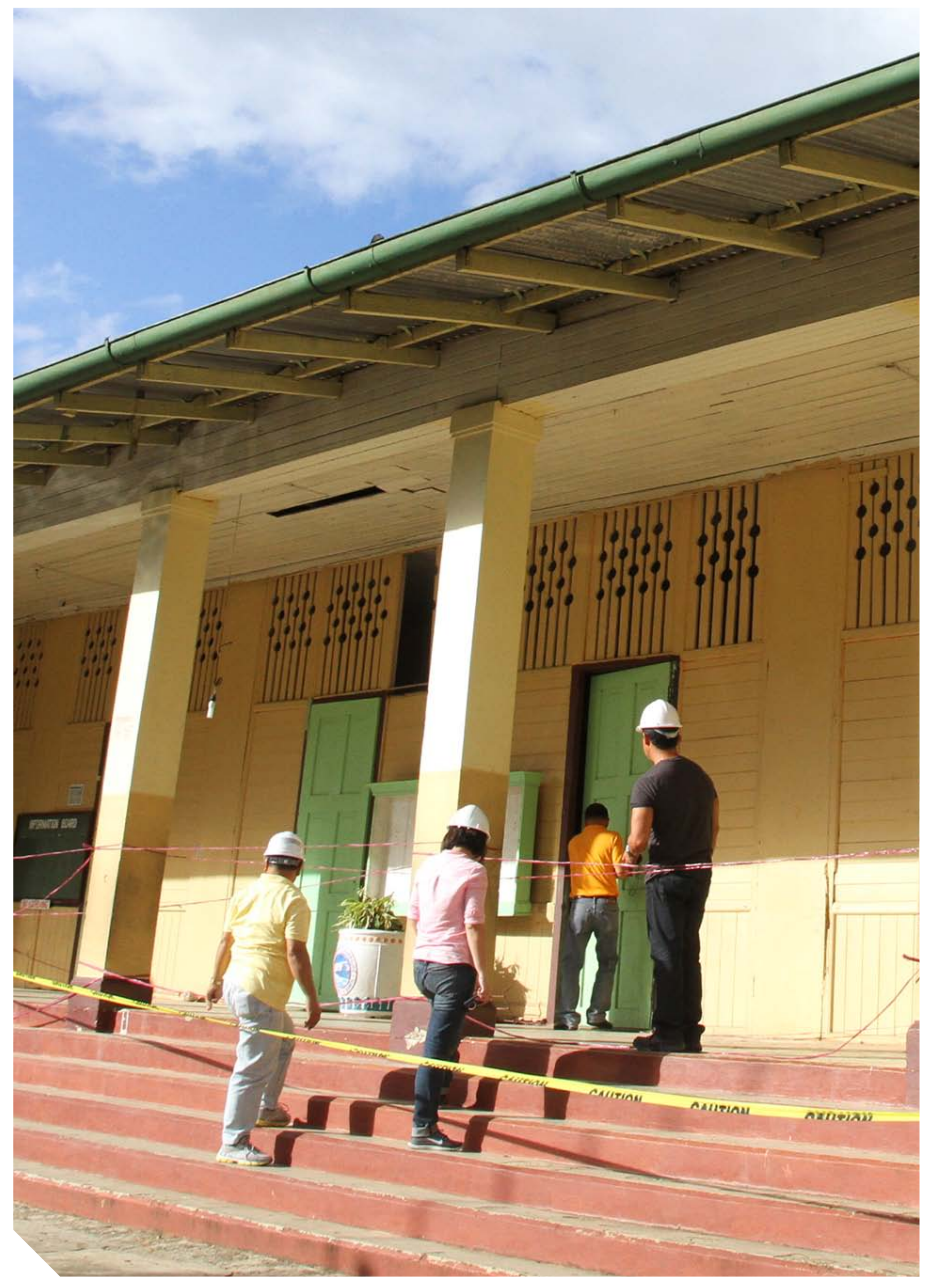

This note is part of a series outlining analysis and results from the Philippines Public Expenditure Tracking and Quantitative Service Delivery Study conducted by the Department of Education and the World Bank with the support of the Australian Government through the Australia-World Bank Philippines Development Trust Fund. 
sample of public elementary and high schools (see Box 1). ${ }^{5}$ It shows that a significant proportion of MOOE funds do not reach schools and that schools serving better-off students tend to receive a larger share of their intended allocation than other schools. While funding for school MOOE has and will continue to increase, these and similar findings demonstrate the need to improve the systems that manage
MOOE funds in division offices and in schools. The findings also highlight the need to strengthen the accountability mechanisms associated with the use of MOOE funds, particularly at the school and community levels. Addressing these weaknesses is likely to significantly improve education outcomes and to support recent school-based management reforms in the Philippines.

\section{Box 1: The Philippines Public Education Expenditure Tracking and Quantitative Service Delivery Study}

The aim of the Philippines Public Education Expenditure and Quantitative Service Delivery Study has been to answer four main questions on the use of the public education budget:

1. Resource flow, management, and control. What factors prevent resources from reaching their intended destination in a timely and transparent manner?

2. Existence, use, and financing of inputs at the school level. Do schools have access to essential inputs and how effective are the systems that govern their use?

3. Equity. How do the resources available to schools and the systems that manage these resources differ among regions and socioeconomic groups?

4. School performance and resources. How and why does the performance of schools differ and what drives those differences?

The study has tracked over 80 percent of the national government education budget (including teacher salaries and training, school maintenance and operating expenses, construction, and learning materials) as well as local government spending on basic education.

In order to assess how funds flow and how they are used at the school level, the study team conducted a nationally representative survey of government institutions and public schools in the last quarter of 2014. The Autonomous Region in Muslim Mindanao was excluded from the study because government funds for this region are managed separately and flow to schools through a different mechanism. In addition, integrated schools (which offer both elementary and high school education) and schools that did not have final grade elementary and high school students were excluded from the sample, primarily because the study aimed to measure outcomes at the end of elementary school and at the end of high school.

The sample for the survey included all regional offices of the Department of Education (DepEd) and the Department of Budget and Management (DBM), 51 division and 113 district offices of DepEd, 54 district engineering offices of the Department of Public Works and Highways, 74 provincial and city/municipality local governments, 249 public elementary schools, and 200 public high schools. At the school level, interviewers administered a questionnaire to each parent-teacher association, assessed the competencies of approximately 1,500 teachers, and interviewed 2,200 student households.

The data collected were used to explore the systems that govern the use of public funds and to assess how the availability of resources differed among schools. The study team combined information on the flow of funds to schools with information on school characteristics and quality to evaluate how financing and governance affected school performance. 


\section{Levels of and Trends in School Operational Funding}

Over recent years, school MOOE funding has increased significantly in real terms even though its share in the overall basic education budget has remained relatively stable. The total school MOOE budget increased in real terms by over 50 percent between 2011 and 2015 (Figure 1). ${ }^{6}$ The biggest increase during this period was associated with the introduction in 2013 of a new formula for allocating school MOOE funding. These large overall increases in the school MOOE budget have translated into even larger increases in per-student funding levels. For example, between 2011 and 2014, per student appropriations for elementary school MOOE increased from PHP 317 (US\$7) to PHP 566 (US\$13).

Public schools rely heavily on the school operating funds provided by the national government. The PETS-QSDS study collected detailed information on all types of school revenues. In 2013, MOOE allocations accounted for 68 percent of all discretionary funding received by elementary schools and 82 percent received by high schools. In the case of over 10 percent of schools, their MOOE allocations were the only source of operational funding that they received.

Despite the importance of MOOE allocations to schools and despite recent increases, a detailed costing study has revealed that existing levels of school MOOE do not cover the full operating costs of public elementary and high schools. ${ }^{8}$ The study reviewed existing DepEd service standards and norms for elementary and high schools and collected data and information on the funds needed to meet each of these standards. After verifying its findings with DepEd staff and school principals throughout the Philippines, the study concluded that overall levels of elementary and high school MOOE funding will need to more than double if existing service standards are to be met.

\section{Assessing the Systems that Govern the Allocation and Use of School MOOE Funds}

\begin{abstract}
Allocation
As in other countries, MOOE allocations in the Philippines are based on school and student characteristics. DepEd introduced a funding formula for school MOOE allocations for the first time in 2013 (Table 1). According to the new formula, in 2013 the average elementary school was allocated approximately PHP 170,297 (US\$3,720) and the average high school was allocated PHP 744,358 (US\$16,180). ${ }^{9}$

However, the amount of MOOE funds that is actually allocated to each school is frequently different to the
\end{abstract}

Figure 1: National MOOE Funding for Schools Has Increased Significantly in Recent Years

Total and per student appropriations for school MOOE, 2005-2015 (in 2014 constant prices)

Total appropriations

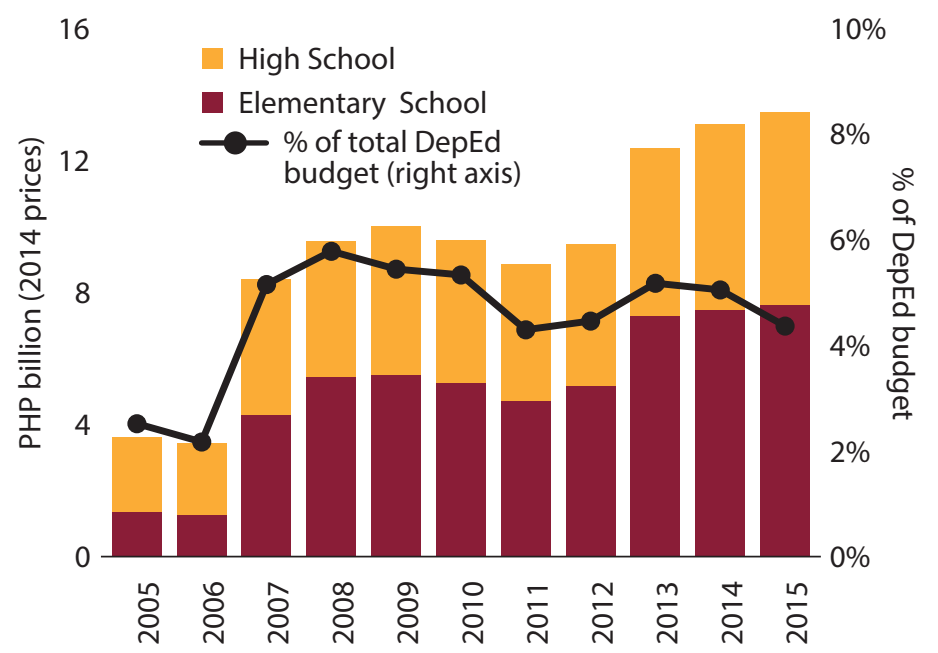

Appropriations per-student

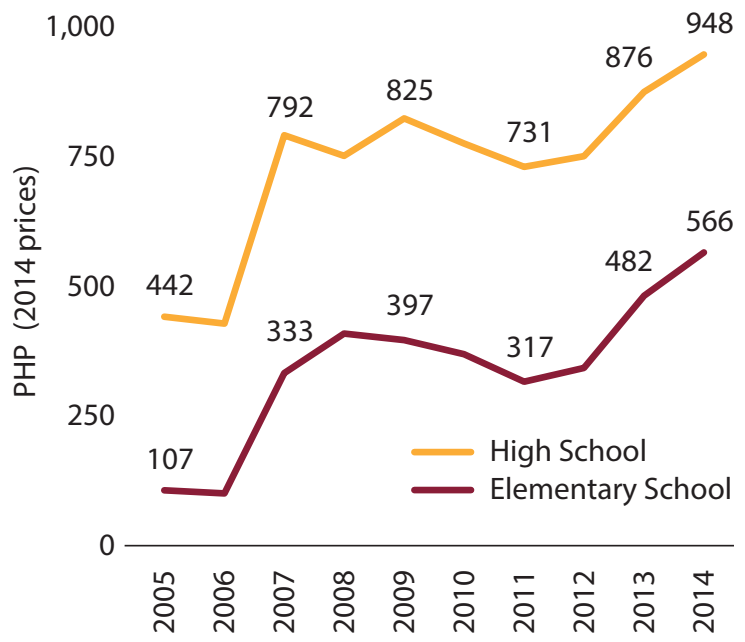

Sources: National government appropriations from General Appropriations Act, various years. Enrollment data come from DepEd Fact Sheets, various years. 
Table 1: Components of the MOOE Allocation Formula

\begin{tabular}{|c|c|c|c|c|}
\hline \multirow[b]{2}{*}{ Allocation component } & \multicolumn{2}{|c|}{2013 to 2015} & \multicolumn{2}{|c|}{2016} \\
\hline & $\begin{array}{l}\text { Elementary } \\
\qquad \text { (PHP) }\end{array}$ & $\begin{array}{l}\text { High Schools } \\
\text { (PHP) }\end{array}$ & $\begin{array}{c}\text { Elementary } \\
\text { (PHP) }\end{array}$ & $\begin{array}{l}\text { High Schools } \\
\text { (PHP) }\end{array}$ \\
\hline 1. Fixed & 40,000 & 80,000 & 50,000 & 96,000 \\
\hline 2. Per Student & 200 & 400 & 250 & 480 \\
\hline 3. Per DepEd Teacher & 4,000 & 8,000 & 5,000 & 9,600 \\
\hline 4. Per classroom & 3,000 & 6,000 & 3,750 & 7,200 \\
\hline 5. Per graduating student & 250 & 250 & 313 & 300 \\
\hline
\end{tabular}

Notes: Prior to 2016, the fixed component for technical and vocational high schools was PHP 160,000. DepEd follows a no diminution policy that, in any given year, prevents a school's MOOE from being less than its level in the previous year.

amount prescribed by the formula. For example, in 2013 the allocations of MOOE funds to elementary schools differed from the expected amount based on the formula by PHP 7,000 or approximately 4 percent of the average allocation for each school. In the case of a small number of schools, the allocation differed from the formula by as much as PHP 50,000. ${ }^{10}$ Possible reasons for these discrepancies include confusion over which types of classrooms are included in the formula and DepEd's "no diminution policy," which prevents a school's MOOE funds in any given year from being less than the previous year's level. However, it is difficult to identify the main causes for each school because school-level data on the formula components (for example, on the number of students in each school) is not published on DepEd's website alongside the data on school-level MOOE allocations. This prevents school officials from being able to understand any discrepancies in their MOOE allocations and reduces the benefits, in terms of increased transparency, that a funding formula can provide.

The limited knowledge that education stakeholders have of the funding formula reduces accountability for MOOE allocations. While over half of all school principals claim to be aware of the MOOE formula, fewer than one in ten know the formula's components and hardly any know the funding associated with each component (Figure 2).

\section{Figure 2: Knowledge of the MOOE Formula among Education Stakeholders is Limited}

Percentage of stakeholders who are aware of MOOE funding and its components
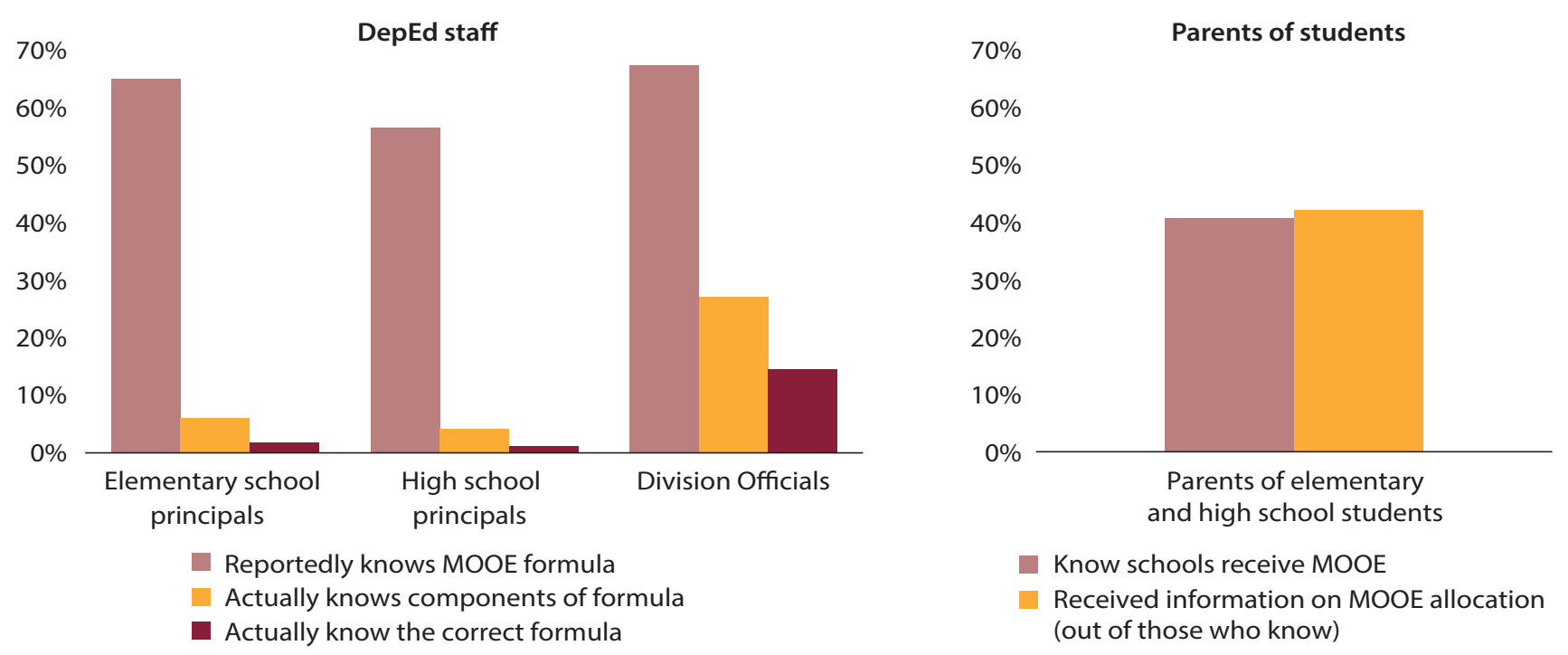

Source: PETS-QSDS national survey - division, school, and household levels. 


\section{Box 2: Approach to Tracking}

In order to track the flow and use of MOOE funds, the study team obtained from official records maintained by Division offices the amount they received for school MOOE, and on the amount they reported downloading to each PETS-QSDS sample school and for each MOOE advance. The records also included details on the check number, the date of check, the date on which the check was collected by schools, and the date on which the corresponding liquidation report was submitted. The same set of information was collected from records maintained by schools. In addition, the team collected information on the types of expenditures for which the schools used their MOOE funds from school liquidation reports corresponding to each MOOE advance downloaded to the school from the division office.

Knowledge of the allocation formula is also limited among DepEd's division officials. The study team's interviews with student households also revealed a lack of awareness among parents. Only 40 percent of parents were aware that schools receive MOOE funds, and the majority did not know how MOOE funds were allocated. With no knowledge of the formula, schools, division offices, and parents cannot confirm whether the schools are receiving the correct allocation and are unable to seek redress in cases where their funding falls below expectations.

\section{Transfer of MOOE Funds to Schools}

The PETS-QSDS study tracked MOOE funds from their initial allocation in the DepEd central office all the way down to their receipt by a nationally representative sample of schools. Implementing unit (IU) high schools were excluded from the analysis since they follow a different system for receiving and reporting on funds. The survey used official records (such as notices of cash advancements, checks, and liquidation reports) to record the receipt and downloading of funds from each administrative level and to schools (Box 2).

The main finding of this tracking exercise is that only 77 percent of the total allocations for elementary and nonIU high schools ultimately reached those schools in 2013 (Figure 3). ${ }^{11}$ In other words, elementary and high schools received only PHP 448 of the PHP 581 allocated for each student. Given that the guidelines stipulate that all school MOOE funds should be downloaded to schools, this finding is a concern. It implies that about PHP 1.8 billion out of the PHP 8 billion MOOE budget intended to be used by schools in 2013 were not downloaded. ${ }^{12}$

Figure 3: A Significant Portion of the MOOE Allocations Do Not Reach Schools

Share of MOOE allocation downloaded and received by schools, 2013

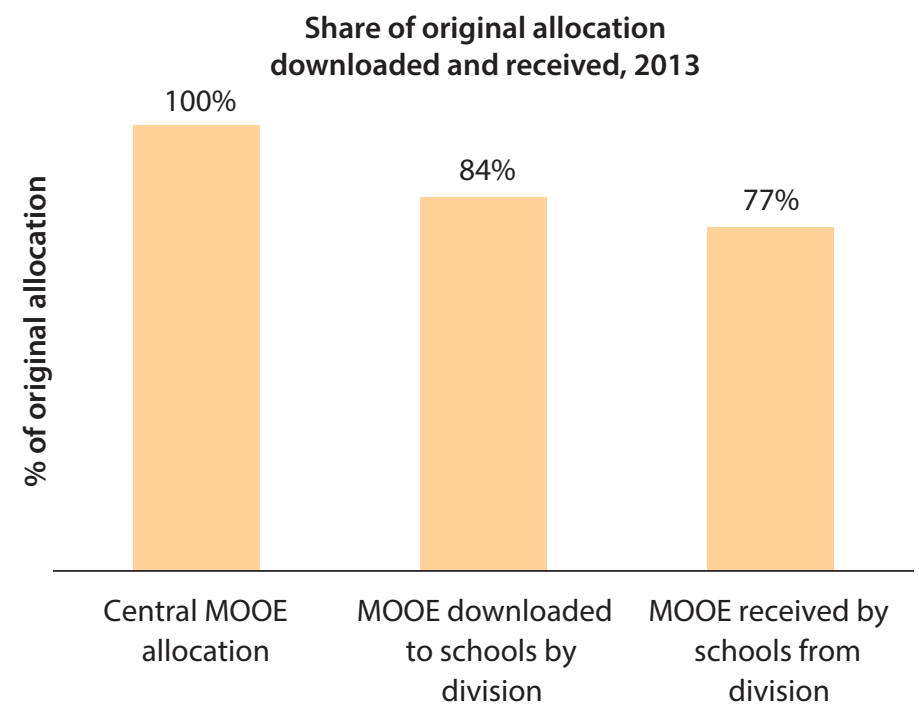

Proportion of schools

$100 \%$

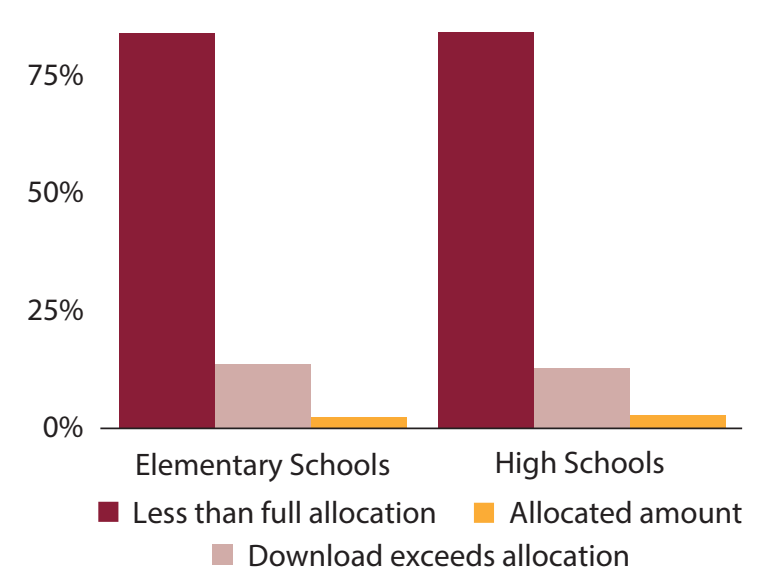

Sources: Data on allocations from DepEd central office. All other data from PETS-QSDS national survey - division and school levels. 
These aggregate findings can be explored further to identify the key stages where school MOOE funds are diverted. The first stage relates to differences between DepEd central office allocations and how much DepEd division offices actually report downloading to schools. The second stage relates to differences in the amount that DepEd division offices report downloading to schools and the amount that schools, through their records (for example, liquidation reports), report receiving.

Differences between DepEd central office allocations and the amount of MOOE funding that the division offices downloaded to schools account for the largest share of funds that fail to reach schools. These differences account for 16 percent of the 23 percent of school MOOE funds that do not reach schools. The records show that DepEd division offices failed to download the full allocation to over 80 percent of elementary and non-IU high schools in 2013 (Figure 3). In many schools, these differences were large; in around 20 percent of elementary schools and 15 percent of high schools, the amount downloaded by division offices was less than half of the schools' original allocation. These under-allocations were partly offset by over-allocations to some other schools; approximately 13 percent of schools were given amounts that exceeded their allocation. ${ }^{13}$

The retention of school MOOE by Division offices is the main factor behind differences between initial allocations and the funds downloaded to schools. While a 5 percent deduction by the Department of Budget and Management (DBM) for tax purposes explains part of the gap between the MOOE funds allocated and received, the bulk of the gap at this level is explained by division offices withholding funds.

Although division offices are required to download funds to schools in full, the tracking exercise indicates that over 60 percent of divisions held onto some MOOE funds in 2013.14 They did so to procure items for schools, to pay their utility bills, or to fund other services for schools (Figure 4). This is the case even though DepEd explicitly prohibits divisions from procuring items using school MOOE funds except in extreme cases where there is a demonstrated need for the division to do the procurement. This practice reduces the amount of discretion that schools have over the use of their own MOOE funds and has the potential to limit the effectiveness of ongoing school-based management reforms. Procurement by divisions also makes it difficult to

\section{Figure 4: Divisions Retain MOOE Funds to Spend on Behalf of Schools}

Reasons why DepEd division offices retain MOOE funds (\% of divisions), 2013

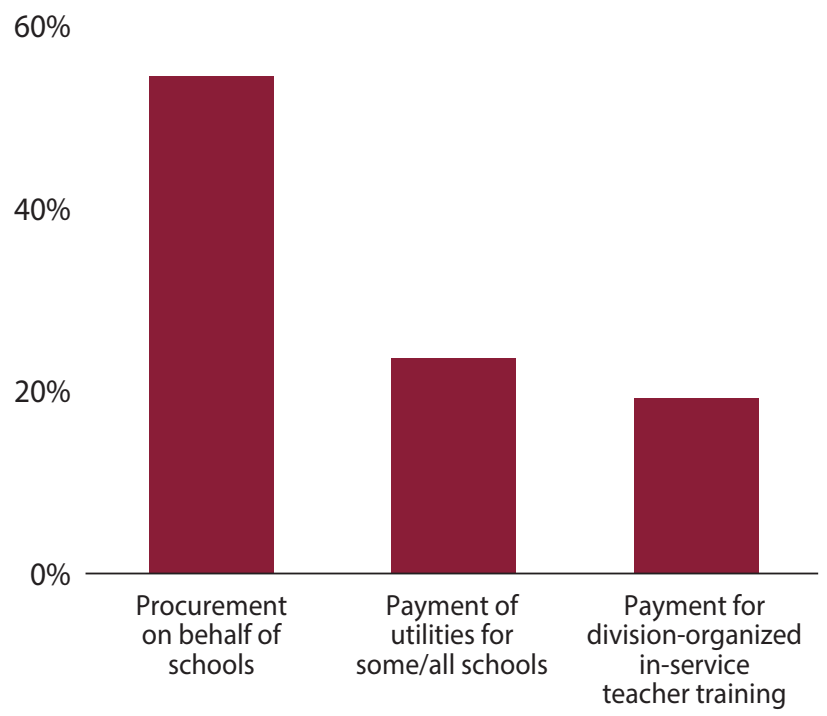

Source: PETS-QSDS national survey - division and school levels. Note: Only divisions that reported retaining funds are included.

monitor whether school MOOE funds are being used for their intended purpose as schools have no way of verifying how the divisions used the retained funds.

Smaller discrepancies are also evident in the second stage of the flow of MOOE funds to schools. Of the 23 percent of school MOOE funds that do not reach schools, 7 percent can be accounted for at this stage (Figure 3). ${ }^{15}$ However, the poor quality of records at the school level makes it difficult to make a full accounting of the extent of the funds diverted at this stage. While it is possible to compare the aggregate annual amount of MOOE funds downloaded by divisions to schools with the amounts that the schools received, gaps in the records kept at the school level stymie efforts to identify the sources of the discrepancies. For example, at the school level, one-third of the entries recording the schools' receipt of the MOOE transfers do not include a check number, which makes it impossible to compare them with each individual check sent by the division. Such gaps in documentation emphasize the need to strengthen MOOE reporting processes at every level.

Any delays by DepEd division offices in downloading MOOE funds to schools not only prevent schools from receiving 
those funds in a timely manner but also reduces the total amounts that they receive. For example, in 2013, while most division offices downloaded the first advances to schools at the beginning of the calendar year, around 10 percent of schools did not receive their first advance of MOOE funds until the start of the school year in June (see Figure 5). Schools that receive their first advance late also tend to receive a smaller share of their total allocation. For example, elementary schools that received their first advance in February 2013 received approximately 80 percent of their full allocation whereas schools that received their first advance after August received less than a quarter of their full allocation. ${ }^{16}$

Any irregularity in the downloading of MOOE funds makes school planning more difficult and potentially less efficient. In 2013, 20 percent of elementary schools and 25 percent of high schools received MOOE funds from division offices every month, but 34 percent of elementary schools and 30 percent of high schools received only five advances in the whole financial year. In the remaining schools, downloading did not follow any regular pattern. ${ }^{17}$

\section{School Management of MOOE Funds}

The late downloading of MOOE funds by divisions is compounded by delays on the part of schools in collecting their MOOE checks. A comparison of the issuing and collection dates of MOOE checks shows that only 40 percent of elementary school checks and 20 percent of high school checks were collected from the division offices on the day on which they are released. These collection delays can be quite long. Over one-third of MOOE checks were collected more than two weeks after they were issued. In some cases, when transfers are delayed or unpredictable, school principals use their personal funds or raise money from teachers to cover the school's operating expenses. School liquidation reports show that in 2013 over 60 percent of elementary school and 45 percent of high school principals paid for approximately 5 percent of their operating expenses from their own funds while they waited for their MOOE funds.

School liquidation reports reveal that some schools find it difficult to use all of the MOOE funds that they receive. Although schools are required by law to spend all of the MOOE funds that they receive, around 70 percent of schools

\section{Figure 5: Schools Often Do Not Receive their Full Allocation of MOOE Funds Because of Delayed and Unpredictable Transfers by Division Offices \\ Timing of first MOOE advance and share of overall allocation received, 2013}

\section{Cumulative share of schools by receipt of first MOOE advance, 2013}

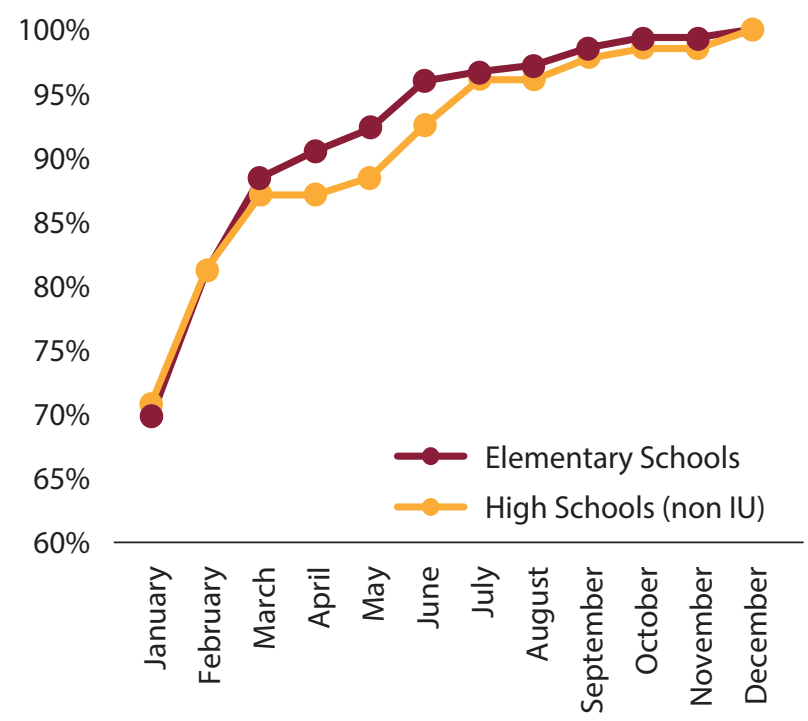

Share of total MOOE allocation received by month of first advance, elementary schools, 2013 $100 \%$

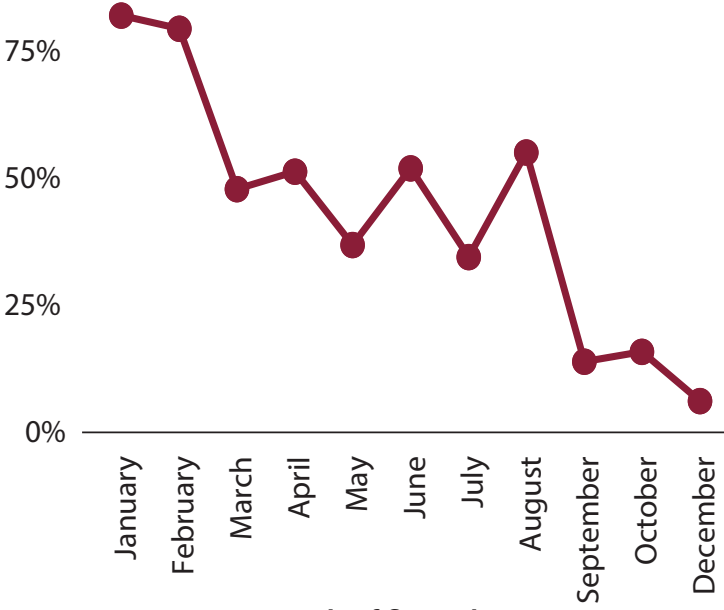

Month of first advance

Source: PETS-QSDS national survey - school level. 
were unable to do so in 2013. On average, a quarter of MOOE funds received by these schools went unspent. The underspending of available MOOE funds is especially concerning because other studies have revealed the inadequacy of current levels of MOOE to meet schools' needs. ${ }^{18}$ However, any efforts to persuade the government to raise the MOOE budget will meet with only limited success unless these school liquidation difficulties are overcome.

The main reason why so many schools find it difficult to spend their entire MOOE allocation is because they have insufficient capacity and time to meet their reporting and procurement requirements. Over a third of elementary schools and a quarter of high schools reported encountering such problems in 2013, and the lack of capacity to meet reporting requirements was one of the most commonly cited challenges (Figure 6). Other salient problems included difficulties locating suppliers and canvassing. ${ }^{19}$ School principals also reported having insufficient time to spend MOOE funds in general. Although fewer schools reported facing such issues in 2014, their primary challenges remained the same - a lack of time and insufficient capacity.

Smaller elementary schools and those in rural areas are more likely to struggle to spend their MOOE resources. For example, the elementary schools that reported facing such issues had an average allocation of PHP 132,500 each compared with the average of PHP 191,600 for elementary schools that reported experiencing no difficulties in spending their allocations. The lower allocation reflects the smaller number of students in schools facing liquidation difficulties. Small high schools were also more likely to find it difficult to spend their MOOE funds, but the differences between small and larger high schools were not statistically significant. ${ }^{20}$

The management of MOOE funds is particularly demanding on school principals. In the 2014 school year, principals reported spending six to eight hours a week on administrating MOOE funds, including procuring goods and services and preparing liquidation reports (Figure 7). It is possible that a key factor that determines the time needed to process MOOE funds is related to the location of the school. For example, for schools far away from division offices and markets, it takes more time to collect their MOOE checks and to find suppliers. However, the study team's analysis shows that this is not the case nor is it related to whether schools are located in rural or urban areas (Figure 7). The team's findings suggest that the bulk of the time that school principals spend on managing MOOE funds goes on activities that are common to all schools such as reporting and canvassing.

The difficulties that school principals experience in managing MOOE funds can result in significant delays in their submission of liquidation reports as well as some misreporting of data. Although schools are usually required to submit liquidation reports within 35 days of receiving

\section{Figure 6: Schools Do Not Have Enough Time or Capacity to Spend All of Their MOOE Funds}

Challenges experienced by schools in spending MOOE funds, 2013/14 school year

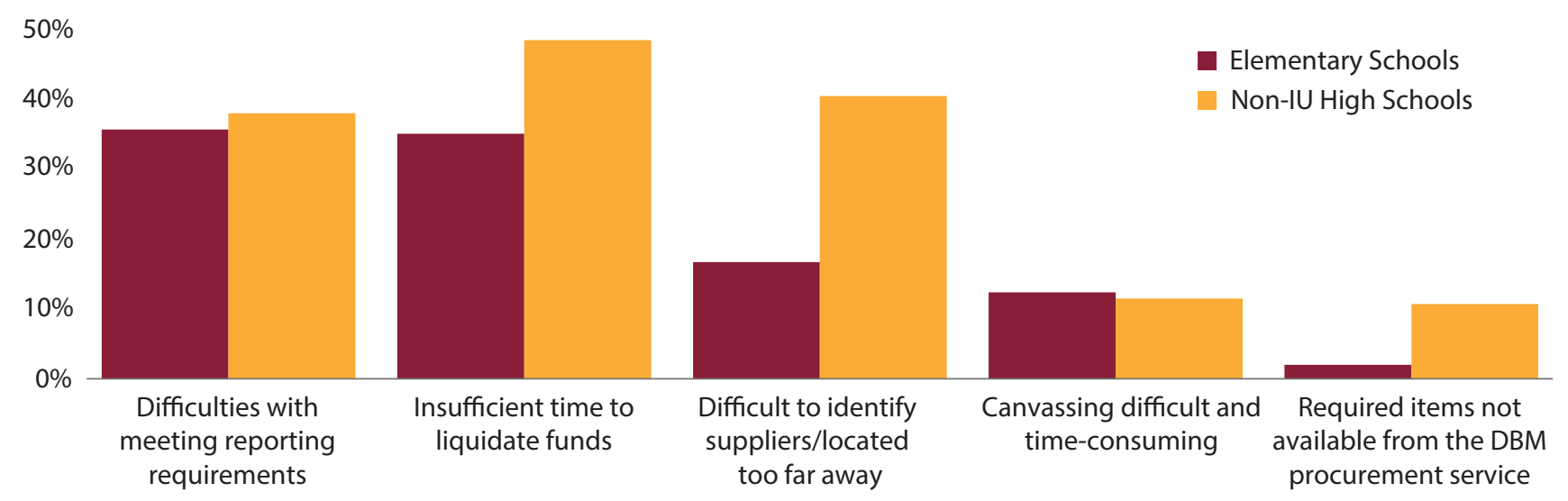

Source: PETS-QSDS national survey - school level.

Notes: Only schools that reported experiencing difficulties in spending their MOOE allocations are included. 
Figure 7: Managing MOOE Funds at the School Level is Time-consuming

Average hours spent on MOOE administration per week by schools' distance to division office, 2014 school year

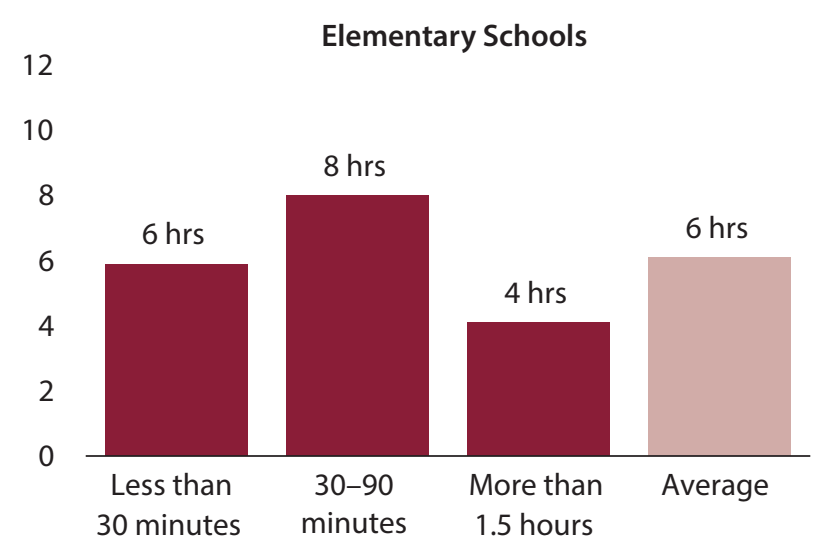

Time to travel to Division office from school

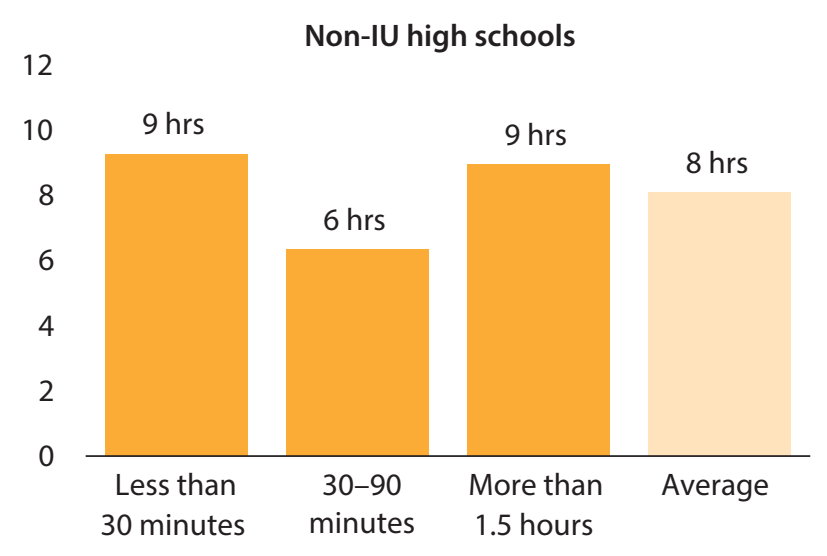

Time to travel to Division office from school

Source: PETS-QSDS national survey - school level.

Note: The label above the bars shows the average number of hours taken to administer MOOE funds by schools located at different distances from their division office.

an MOOE advance only about half of all elementary school advances and one-third of high school advances were submitted within this period. ${ }^{21}$ Some schools submit reports as long as three months after the initial advance was made.

Moreover, division officials report that these delays are a leading cause of their own delays in downloading MOOE funds to schools. This is the case because schools are not allowed to receive their next MOOE transfer unless they submit a complete and correct liquidation report on how they spent the previous transfer. Of the 37 percent of division officials who reported delays in downloading MOOE funds to elementary schools in 2014 and the 31 percent who reported delays in transferring MOOE funds to non-IU high schools, over half of them cited late liquidation reports as the reason, while more than a third (for elementary schools) and a quarter (for high schools) mentioned problems with previous liquidation reports.

\section{Equity of School MOOE Funding}

Schools serving poorer and more marginalized groups are provided with higher levels of MOOE funding for each student. The PETS-QSDS survey included a nationally representative sample of the households of public elementary and high school students. Using information collected on consumption and asset ownership collected in the survey, it is possible to rank student households by estimated levels of per capita household consumption. ${ }^{22}$ This indicator of household welfare reveals that elementary students from poorer households are more likely than students from wealthier households to attend schools that have higher per capita allocations of MOOE funds (Figure 8). This is not because the MOOE funding formula provides additional funding to schools serving poorer groups. Instead, this is partly a reflection of the fact that wealthier students are more likely to attend schools in urban areas where student-classroom and studentteacher ratios are higher, thus leading to lower per-student MOOE funding (Table 1). High schools serving the poorest students also have higher per-student allocations than those serving the wealthiest students, but the difference is not statistically significant.

However, in elementary schools, the pro-poor allocation virtually disappears in terms of the amount of MOOE funding that the schools actually spend. The result is that, in practice, students from different socioeconomic groups attend schools that receive similar levels of per-student MOOE despite the large differences in their original allocations. This is a missed opportunity to use school MOOE as a way to narrow the very large differences 
Figure 8: The MOOE Funds that Schools Receive Do Not Reduce Inequalities in Overall School Funding Elementary school per-student funding by source, 2013 and 2013/14 school year
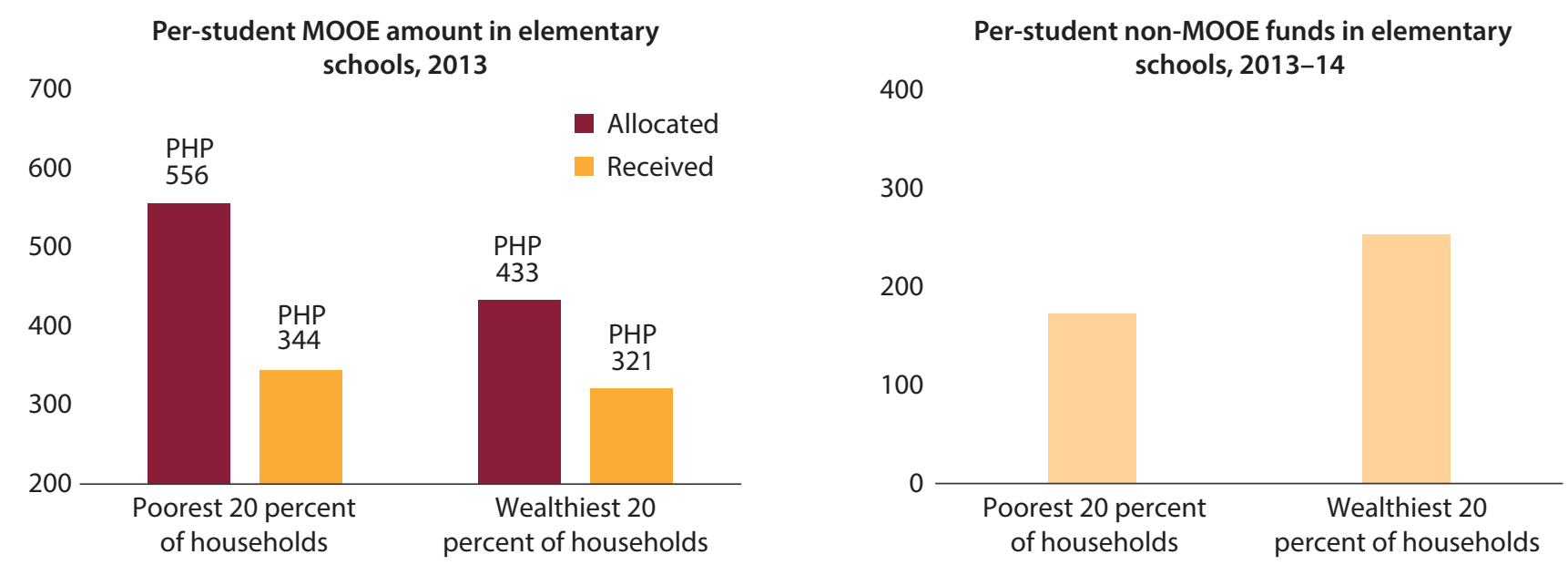

Source: PETS-QSDS national survey - school and student household levels.

Notes: Non-MOOE sources are all other cash contributions received by schools directly (e.g. local government, Parent Teacher Associations, fees) and school based management grants. A full description of the funding sources included and the approach to estimating overall school revenue is contained in additional tables to the full PETS-QSDS report.

in school revenue among schools serving different socioeconomic groups (Figure 8).

The PETS-QSDS findings also suggest that, among elementary schools, a larger share of the MOOE allocations for schools in poorer areas is not reaching the schools. It might be expected that division offices are managing a larger share of the resources of poorer schools given that they are likely to lack the capacity to manage the funds themselves (Figure 4). Since there is little information on how the division offices spend school MOOE funds, it is not possible to establish whether poorer schools receive their full allocation after any procurement by the division offices is factored in. This significantly reduces the transparency of and accountability for MOOE funds and may be fueling unintended inequalities in levels of school funding.

\section{Oversight and Monitoring of the Use of MOOE Funds}

Schools' liquidation reports show that they spend only a small proportion of their MOOE funds on prohibited items. Over 80 percent of school MOOE expenditures are spent on allowable items (Table 2 and Figure 9). However, in 2013, elementary schools used 5 percent of their MOOE funding to purchase equipment and instructional materials prohibited under current guidelines, while high schools used 2 percent of their funding on prohibited items. Approximately 10 percent of total school MOOE expenditures were not reported on liquidation reports so it was not possible to assess whether those expenses were eligible.

Table 2: Allowed and Prohibited Spending Categories for MOOE Funds

Allowable expenses
Supplies for teaching, utility payments, minor repairs, travel,
wages for janitorial services, teacher training, graduation
ceremonies, and other activities identified in the School
Improvement Plan (SIP).

\section{Ineligible expenses}

Textbooks and instructional materials (such as publications, periodicals, or review materials), furniture and equipment, and teacher salaries. 
Figure 9: Most MOOE Funds Are Spent in Accordance with Existing Guidelines

Percentage of total MOOE expenses by item of expenditure, 2013
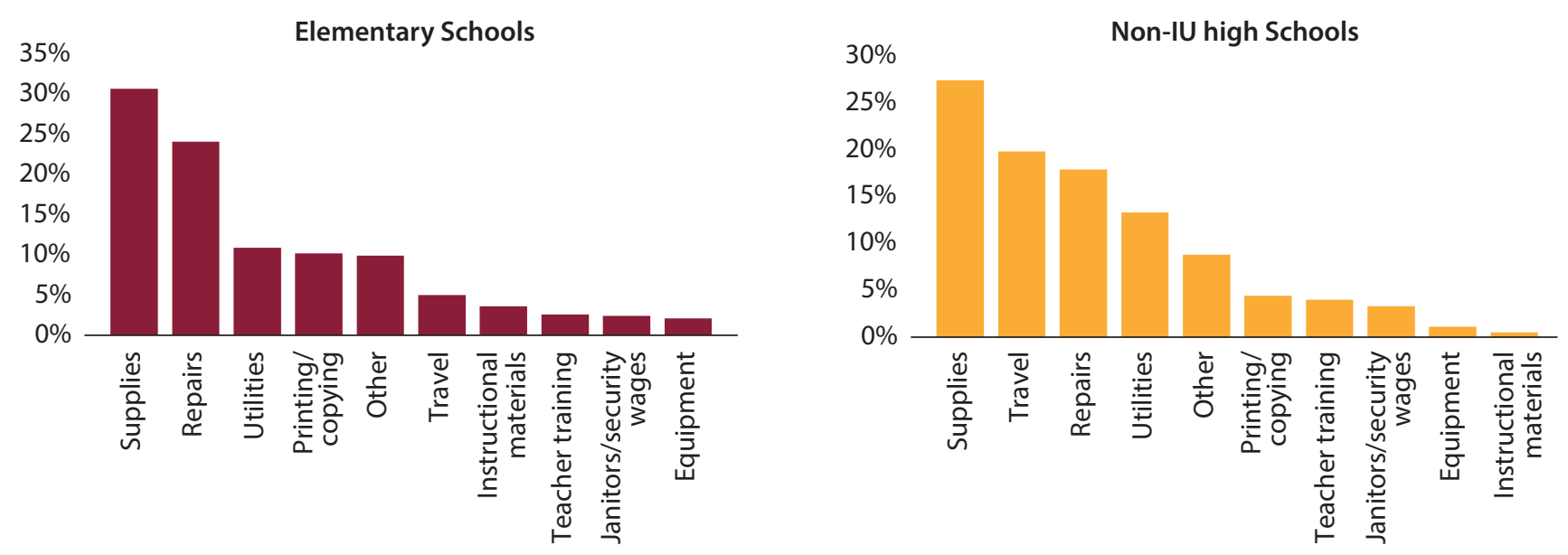

Source: PETS-QSDS national survey - school level.

The schools' records also reveal that the proportion of funds that they used to purchase items directly related to learning was relatively low. For example, elementary schools spent only 3 to 4 percent of their total MOOE expenditures on teacher training and only 4 percent on purchasing instructional materials such as periodicals or review materials.

While there are regulations in place that aim to strengthen the transparency over MOOE use, compliance with these regulations is low. The Anti-Red Tape Act (2007) mandates public schools to maintain a transparency board or bulletin board detailing how they are using their MOOE funds.
However, as of 2014, fewer than two-thirds of schools had a transparency board containing information on MOOE expenditures (see Figure 10). Moreover, the information posted on about a third of transparency boards was more than three months old.

Another factor that contributes to weak monitoring is the lack of knowledge among stakeholders of the rules governing MOOE funds. Although schools are legally required to publicly disclose how they use their funds, there is no specific law requiring them to post information on their expenditures on allowable and prohibited items. Not

Figure 10: Schools' Compliance with the Transparency Board Requirement is Low

Percentage of schools that had transparency board displaying MOOE information in 2014
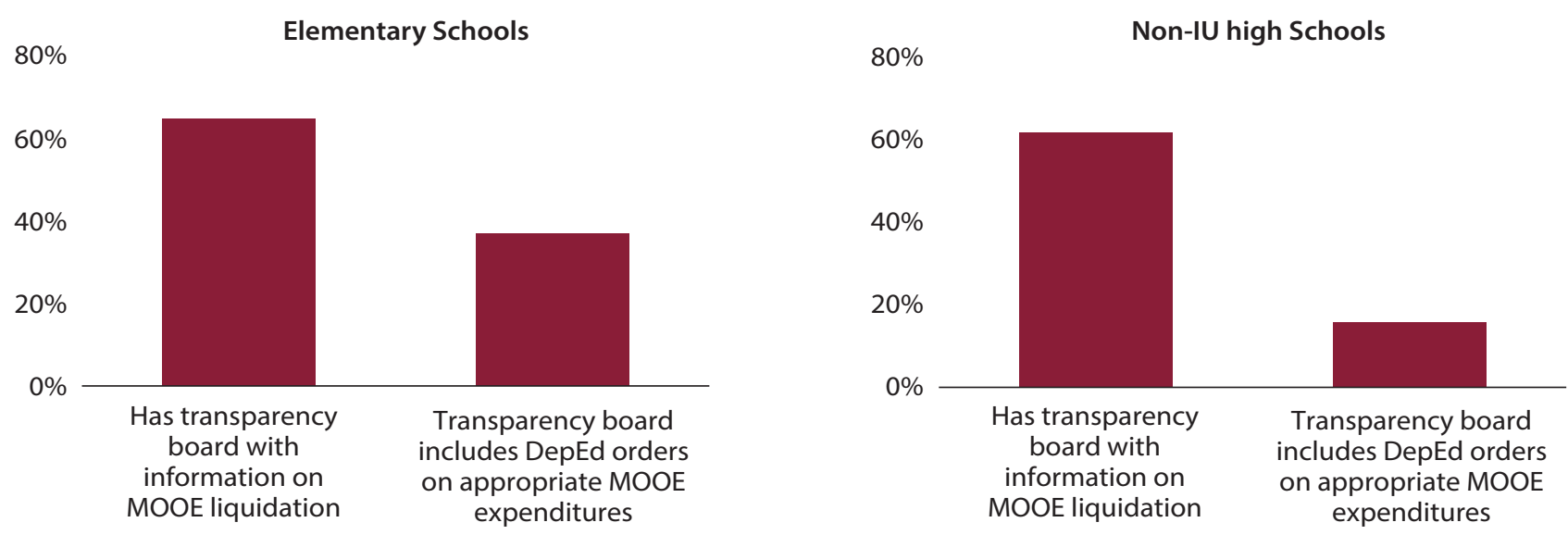

Source: PETS-QSDS national survey - school level. 
surprisingly, only about half of the elementary schools and a quarter of the non-IU high schools that have transparency boards post DepEd's orders on the appropriate use of MOOE funds (Figure 10). This lack of information makes it difficult for parents and other local stakeholders to judge whether the funds are being used appropriately.

Decisions on the use of MOOE funds are largely confined to the school principal and other teachers. In 2014, over 80 percent of schools reported that teachers had been consulted about how to use the schools' MOOE funds (Figure 11). PTAs have an input into how MOOE funds are used in fewer than 30 percent of schools. This is not surprising since DepEd's current guidelines explicitly prohibit PTAs from "interfering in schools' administrative management."23

Only 13 percent of elementary schools receive input from school governing councils (SGCS) even though SGCs are responsible for developing and implementing the school improvement plan (SIP), which includes activities financed by MOOE funds. ${ }^{24}$ This number is even lower among non-IU high schools, with SGCs, parents, and local school boards participating in MOOE decisions in fewer than 10 percent of schools. The study's interviews with parents revealed a similar picture. Only about one-third of parents reported participating in discussions about the school's use of financial resources in general and fewer than a quarter reported participating in decisions about how to use the school's MOOE funds.

\section{Policies to Strengthen the Allocation, Implementation, and Accountability of MOOE Funds}

\begin{abstract}
This note has shown that the bulk of MOOE funds are transferred to schools and that schools use these funds for the purposes for which they were intended. However, in light of the government's plans to significantly increase school operational funding, it will be necessary to tackle the remaining weaknesses to ensure that these funds are used in the most effective way to improve education outcomes. It is crucial that the system for allocating and managing MOOE funds is strengthened to ensure that schools receive their allocations in full and in a timely manner. The current problems that some schools face in spending these funds fully and in an effective way also need to be solved. Increasing the transparency and oversight of fund use by involving school governing councils and parents could be an effective way of improving school management of MOOE funds. The note also found significant funding inequalities between schools serving disadvantaged groups and those serving children from better-off households. Adjusting the MOOE allocation formula to include an equity component would narrow these funding differences and thus improve education outcomes.
\end{abstract}

Figure 11: There Is Little Participation by Local Stakeholders in Decisions about How MOOE Funds Are Used Percentage of schools that received input from stakeholders about MOOE funds, 2014 SY

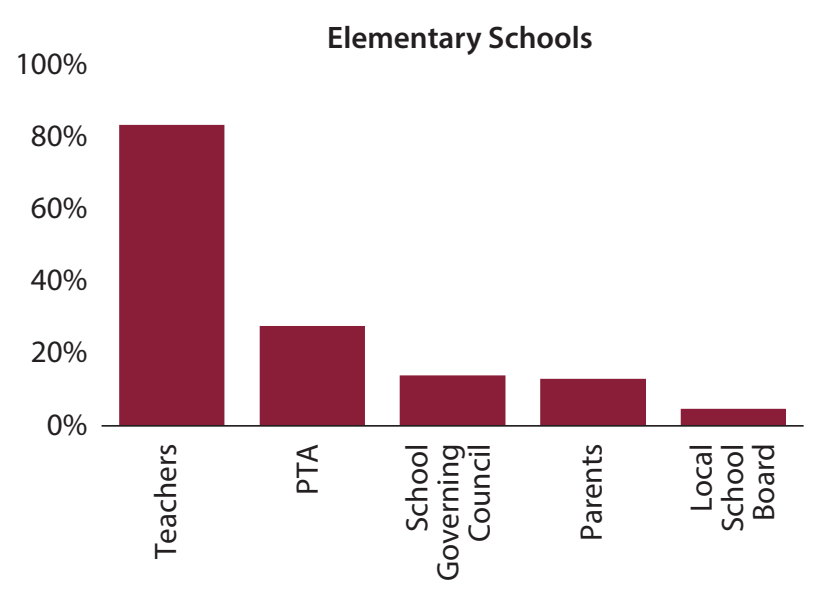

100\% Non-IU High Schools

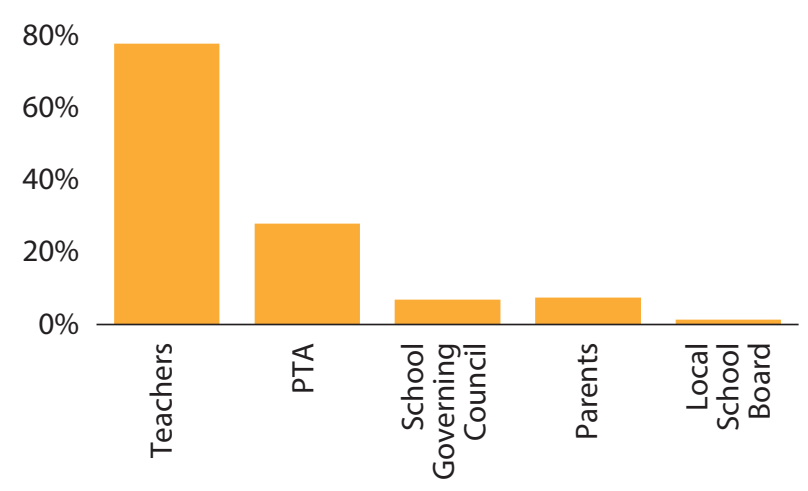

Source: PETS-QSDS national survey - school level. 


\section{Improving the Flow of MOOE Funds to Schools}

Ensuring that division offices download all allocated MOOE funds to schools would be an important first step in improving the use of MOOE funds. Tightening and enforcing the rules governing division offices procuring material on behalf of schools would reduce the extent to which division offices retain MOOE funds rather than transfer them directly to the schools. Even in cases where centralized procurement may be more efficient, the division offices could still download the funds to schools, who could then pay the division offices for any goods and services procured on their behalf. This would also ensure that these funds are properly accounted for in school liquidation reports and make it easier for all MOOE funds to be monitored. Setting division office targets for the full and timely downloading of school MOOE funds and tying these to performance-based bonuses (PBB) would also facilitate the flow of funds.

Stepping up monitoring efforts will also be essential to improve the flow of funds to schools. The current reporting requirements hinder the effective monitoring of $\mathrm{MOOE}$ downloading to schools. While division offices are required to submit monthly reports on the status of downloading and utilization to the Office of the Secretary, there is no mechanism to verify whether each school in the division has received their full allocated amount. Establishing a system to provide this information as well as a feedback mechanism for schools to inform DedEd about the fund transfers that they have received would go a long way towards strengthening monitoring.

In order to strengthen accountability, it is vital that schools and other stakeholders know the details of the funding formula and the correct MOOE allocation for each school. A first step would be to enforce the existing requirement for division offices to inform schools about their allocation at the beginning of the fiscal year. Moreover, posting the criteria used to determine the allocated amount for each school (such as the number of teachers and classrooms) online as well as on the division office transparency board at the beginning of the year would strengthen accountability.

\section{Simplifying the Liquidation Process and Supporting the Management of MOOE Funds}

Simplifying the existing requirements for schools to prepare liquidation reports on how they used their MOOE funds would reduce the significant burden that this currently puts on schools. It would also give school principals more time to focus on providing academic leadership in their schools. One approach that has been adopted in other countries would be to treat MOOE funds as grants. For example, this is the case in Indonesia, where these funds now have much less onerous reporting requirements than required by the usual government budget and implementation systems. ${ }^{25}$ Schools use simplified reporting templates to report on their use of the funds and submit these reports to district (division) offices every quarter. The Indonesian system also encourages much more involvement by school committees (school governing councils) in overseeing the use of school MOOE funds, a role that used to be played by the district office, and this has strengthened monitoring. Developing a similar system, adjusted for the specific context of the Philippines, could reduce the burden on schools and at the same time strengthen oversight of the use of funds.

Reducing the frequency of transfers from once a month to once a quarter would make procurement processes more efficient and would reduce the time that school principals would need to spend preparing liquidation reports. Releasing larger sums on a less frequent basis would make it easier for schools to procure items in bulk for both immediate and future activities instead of having to procure small quantities frequently. It would also reduce the time needed to undertake canvassing and the time spent travelling to make purchases. Less frequent transfers would also reduce the number of liquidation reports that schools would need to submit, which again would reduce the burden on schools.

Extending the current deadline for schools to submit liquidation reports on their MOOE expenditures would further ease their management burden. Giving schools more than the current 35 day limit would give them more time to spend MOOE funds and to do so efficiently. For example, they would have more time to identify the best available suppliers in terms of both cost and quality. 


\section{Box 3: The Pupil Premium in England}

In 2011, the United Kingdom government introduced a "pupil premium."This initiative provides government-funded schools within England with additional per-student funding to raise the attainment of disadvantaged pupils and to narrow the gap between them and other students. In 2014/15, each school received an additional $€ 1,300$ (US\$2,031) for primary-aged students and $£ 935$ (US\$1,461) for secondary-aged students. Rough calculations suggest that an average sized secondary school would receive approximately $£ 200,000$ (US\$312,500) in additional funding through the pupil premium, which is the equivalent of five full-time teachers.

The main criteria used to calculate schools' eligibility for this extra funding is the number of students in the school that have received free school meals over the last six years. Head teachers and school governing bodies are accountable for the use of these funds in two ways. First, performance tables that outline the performance of disadvantaged students compared to their peers are made available to the public. Second, schools are required to publish details online each year of how they have used the premium and what impact it has had.

Schools typically use the additional resources to hire more teachers and teaching assistants in order to introduce special programs for disadvantaged students. In addition, the resources are frequently used to allow eligible students to participate fully in after-school activities.

A recent study of the implementation of the pupil premium found that:

- Schools are using the funding effectively to improve learning outcomes of disadvantaged students and narrowing learning disparities.

- The best schools combine targeted interventions with robust tracking to evaluate their effectiveness.

- School governing bodies take strategic responsibility for student targeting and hold school leaders accountable.

- Challenges remain in schools with weak leadership, including weak governing bodies.

Sources: OFSTED (2014) and www.gov.uk/pupil-premium-information-for-schools-and-alternative-provision-settings.

Schools will need more support and training from the DepEd district level offices to build their capacity to manage MOOE funds. It is not financially feasible to provide a dedicated bookkeeper to each school to manage the administrative requirements associated with MOOE funding. Instead, the role played by district offices in assisting and supporting schools needs to be expanded. In particular, district offices could encourage schools to spend their MOOE funds in accordance with the priorities in their school improvement plans and could help them with the administration of MOOE funds. Providing stakeholders such as teachers, parents, and members of SGCs and PTAs with training on how to spend MOOE funds effectively could also help schools to manage their funds better.

Allowing schools, at least those with bigger allocations, to deposit their MOOE funds in bank accounts would also help them to manage their funds safely. Many schools have to maintain large sums of MOOE funds in cash, which is clearly a security risk. For example, rough calculations suggest that about 22 percent of non-IU high schools with a thousand or more students would have to hold onto more than PHP
100,000 in cash at any given time if the division offices were to transfer allocations to schools on a quarterly rather than a monthly basis. Allowing schools to deposit these funds in bank accounts would overcome this security issue.

\section{Strengthen Oversight over the Use of MOOE Funds by Schools}

Strengthening the role played by school governing councils (SGCs) in overseeing MOOE funds has the potential to lead to more effective use of MOOE funds. While SGCs are already expected to play a role in school improvement planning, their role could be expanded, for example, by requiring them to sign off on liquidation reports and to ensure that the reports are posted on school transparency boards. It will be vital to disseminate information about the current and future responsibilities of the SGCs in order to reinvigorate this important school-level institution and to hold schools more accountable for their use of MOOE and other funds.

Ensuring that $\mathrm{MOOE}$ and other funds that schools receive from both DepEd and other sources are added together and 
treated as a single school budget in the SIP can also increase oversight over use of MOOE funds. Having a single budget in each school can help stakeholders such as teachers and SGCs to identify any potential duplication of expenses and enable effective monitoring of MOOE and other school funds.

\section{Reduce Funding Inequalities by Including an Equity Component in the MOOE Funding Formula}

Introducing an equity component into the MOOE funding formula would be one way to reduce the large school-level funding inequalities highlighted in this note. In order to compensate those schools that receive lower funding from non-DepEd sources such as local governments, an equity component could be introduced in the allocation formula. This could go some way to equalizing school funding and provide schools in poorer areas with the additional resources that they need to support the learning needs of marginalized students. Many other countries, like the United Kingdom, have introduced funding components of this kind (Box 3). MOOE allocations should also be adjusted to take into account price differences between regions so that schools operating in high-cost areas such as remote locations where travel and transportation costs are high are able to purchase similar amounts of goods and services as those in lower-cost locations.

Over the last five years, the Philippines government has provided schools with ever greater amounts of operational funding. While this trend is set to continue, it is imperative that the systems used to allocate and manage MOOE funds are strengthened. Only then will the full potential of funds of this kind to improve education outcomes be realized.

\section{Table 3: Strengthening Systems to Provide Operational Funding to Schools}

\begin{tabular}{|c|c|}
\hline Findings & Policy suggestions \\
\hline $\begin{array}{l}\text { Not all schools receive their } \\
\text { full MOOE allocation and the } \\
\text { transfers are often not made } \\
\text { on a predictable schedule }\end{array}$ & $\begin{array}{l}\text { - Enforce existing regulations on the transfer of funds } \\
\text { - Introduce transfer targets for DepEd division offices tied to performance bonuses } \\
\text { - Make MOOE allocations and formula components for each school publicly available }\end{array}$ \\
\hline $\begin{array}{l}\text { The management of MOOE } \\
\text { funds within schools is } \\
\text { difficult and time-consuming }\end{array}$ & $\begin{array}{l}\text { - Treat school MOOE funds as a grant to simplify reporting requirements } \\
\text { - Reduce the frequency of downloading and increase the time allowed for schools to } \\
\text { - Produce liquidation reports } \\
\text { provide additional support to schools on MOOE management from district offices and } \\
\text { - Allow schools to deposit MOOE funds in bank accounts }\end{array}$ \\
\hline $\begin{array}{l}\text { School-level institutions like } \\
\text { the school governing council } \\
\text { are relatively weak }\end{array}$ & $\begin{array}{l}\text { - Review and strengthen the role of SGCs in the planning and monitoring of MOOE funds } \\
\text { - Disseminate information on the roles and responsibilities of SGCs to parents and the } \\
\text { local community } \\
\text { - Ensure that MOOE and other school-level funds are incorporated into school } \\
\text { improvement plans }\end{array}$ \\
\hline $\begin{array}{l}\text { Funding inequalities at the } \\
\text { school level are large }\end{array}$ & - Introduce an equity component into the MOOE allocation formula. \\
\hline
\end{tabular}




\section{Endnotes}

1 MOOE is different to school grant funding because schools are required to use and account for the use of these funds in the same way as any other recipient of budget funds would be.

2 Khattri, N., C. Ling, and S. Jha (2010). "The Effects of School-based Management in the Philippines: An Initial Assessment Using Administrative Data." Policy Research Working Paper Series. No. 5248, World Bank, Washington, D.C.

3 World Bank and AusAID (2013). "School-based Management in the Philippines: An Empirical Investigation."World Bank and AusAID, Manila.

4 AusAID ERF (2011). "Current Issues in Education: School Grants and School-based Management." Canberra.

5 The findings reported in this note are discussed in more detail in additional annexes and tables accompanying the main PETSQSDS report.

6 Years refer to financial years (January to December) unless otherwise stated.

7 Discretionary funding refers to the funds that schools receive in cash, over which they have discretion to use as they please.

8 World Bank (2016). "The Development and Implementation of a Normative School MOOE Formula in the Department of Education in the Philippines."World Bank, Washington D.C.

9 These averages are based on statistics on the 2013 MOOE allocations from DepEd for the elementary schools in the PETSQSDS sample and from the DBM for high schools.

10 Author's calculations using eBEIS data on enrollment and on the numbers of teachers, classrooms, and graduating pupils for all public elementary schools.

11 The word "allocation" here refers to the cash allocation released by the DBM to DepEd divisions based on authorized allotments and released to cover spending obligations.

12 The study team determined this amount by scaling up the sum of the amounts allocated for public elementary and non-IU high schools in the PETS-QSDS survey to represent nationwide MOOE funding. In addition, they estimated national-level funding for non-IU high schools as about one-quarter of the total funding for high schools (PHP 5.06 billion) as suggested by the data from the DBM on per-school funding for the schools in the PETS-QSDS sample.
13 Occasional congressional insertions (additions to the originally approved budget) or additional MOOE funding for Special Education programs may partly explain why some schools received more than their allocated amount.

14 Interestingly, only a quarter of the divisions admitted to retaining funds when asked.

15 Schools reported receiving only 77 percent of the funds that the division offices reported downloading in the first three-quarters of 2014 .

16 The pattern is similar for high schools.

17 The available data for 2014 show a similar pattern.

18 World Bank (2016). "The Development and Implementation of a Normative School MOOE Formula in the Department of Education in the Philippines." Washington D.C.

19 Canvassing relates to the requirement that schools obtain at least three quotes for purchases that they make with MOOE funds.

20 There were no differences in the proportion of rural and urban high schools that reported finding it difficult to spend their MOOE allocations.

21 More specifically, schools are required to submit a completed liquidation report to the division offices by the fifth day of the month after they have received an MOOE advance in order to receive their next MOOE advance.

22 The household questionnaire included a short module on consumption and a set of questions on assets that have been used by the Department of Social Welfare and Development (DSWD) to undertake a proxy means testing (PMT) approach to estimating household consumption per capita. The results reported here are based on information gathered using the PMT approach, and a full description is included in a separate note.

23 DepEd Order 54, s. (2009). "Revised Guidelines Governing ParentsTeachers Associations (PTAs) at the School Level." Department of Education, Manila.

24 DepEd (2009). "A Manual on School Governing Councils." Department of Education, Manila.

25 Al-Samarrai, Samer; Fasih, Tazeen; Hasan, Amer; Syukriyah, Daim. 2014. "Assessing the Role of the School Operational Grant Program (BOS) in Improving Education Outcomes in Indonesia." World Bank, Jakarta, Indonesia.

\section{WORLD BANK GROUP}

\section{Australian AlD}

